\title{
Study on Physical Properties of Edible Coating of Carboxymethylcellulose Enriched with Lemon and Betel Leaf Essential Oils to Inhibit Browning and Microbial Activity
}

\author{
Nafi Ananda Utama \\ Faculty of Agriculture \\ Universitas Muhammadiyah Yogyakarta \\ Yogyakarta, Indonesia \\ nafi@umy.ac.id
}

\author{
Chandra Kurnia Setiawan \\ Faculty of Agriculture \\ Universitas Muhammadiyah Yogyakarta \\ Yogyakarta, Indonesia \\ chandra.fp@umy.ac.id
}

\author{
Muhammad Syaiful Shodiq \\ Faculty of Agriculture \\ Universitas Muhammadiyah Yogyakarta \\ Yogyakarta, Indonesia \\ shodiqsyaiful24@gmail.com
}

\begin{abstract}
Edible coatings have been used to prevent physiological disorder caused by minimum processing. The aim oh this research is to study about the physical properties of edible film carboxymethylcellulose with the addition of essential oil and its ability to inhibit browning and microbial growth on fresh-cut apples. The research was conducted using an experimental method in Completely Randomize Designed with multiple factors. This research was divided into two steps. The first was edible film carboxymethylcellulose with the addition of essential oil physical properties test, and the second was edible coating application of the fresh-cut apple. Two concentrations of carboxymethylcellulose were used, $1 \%$ and $1,5 \%$. In addition, five variations of essential oils were mixed into the carboxymethylcellulose: no essential oil, $2 \%$ lemon essential oil, $3 \%$ lemon essential oil, $0.1 \%$ betel leaf essential oil and $0,2 \%$ betel leaf essential oil. The results showed that the concentration of $1,5 \%$ carboxymethylcellulose with the addition of betel leaf essential oil had the greatest value on physical properties. The results also showed that the essential oils were incapable of inhibiting browning on fresh-cut Manalagi apple, but essential oil of lemon $3 \%$ could inhibit a microbial activity.
\end{abstract}

Keywords-Apple cv Manalagi, CMC, Edible Coating, Essential Oil, Physical Properties

\section{INTRODUCTION}

The use of edible coating was to reduce effect brought by minimum processing. The aim of semipermeable barrier provided by edible coatings is to extend shelf-life by decreasing respiration, moisture and gas migration, and oxidative reaction also prevent physiological disorders on fresh-cut fruits [1] and [2] Carboxymethyl cellulose (CMC) is a linear, long-chain, water-soluble, anionic polysaccharide that can be used as edible coating for food [3].

Reference [4] stated that lemon has essential oils that are capable of inhibiting the growth of Staphylococcus aurous bacteria. The essential oil of lemon contains $59.7 \%$ limonene, a compound that functions as an antibacterial [5]. Lemon essential oil also contains nerol in which has a synergistic effect on improving the antibacterial activity [6].

Betel leave is known to have some antibacterial effects on several types of bacteria, one of which is Streptococcus mutans. They contain some essential oils with phenols and its derivatives as their main components including the derivatives klavikol that has a bactericidal power [7].
The active compounds of essential oils such as carvacrol, cinnamaldehyde, and cytral have strong antimicrobial properties [8]. For this reason, essential oils are capable of being used to combine with $\mathrm{CMC}$ as antimicrobial. Therefore, this study was conducted to determine the physical properties and microbial inbition ability of CMC edible coating combined with lemon essential oil and betel leaf essential oil and to study $\mathrm{CMC}$ edible coating combined with lemon essential oil on Fresh-cut Apple cv Manalagi.

\section{METHODS}

\section{A. Materials}

Apple was harvested from Batu City orchard, Malang with same age and size with free fruit injury. The sample was then directly brought to Postharvest Technology Laboratory, UMY using a cool box storage. Other materials for making edible coating included CMC (Himedia), glycerol (Bratachem), essential oils of betel leaf and lemon (Happy Green Ltd), aquadest, and microbial soil, and NA microbial growing media (OXOID). This experiment also used a refrigerator, film casting, aluminium frames with the size of $10 \mathrm{~cm} \times 20 \mathrm{~cm}$, water bath, oven, blender, stirrer, glassware, Styrofoam, Water Vapour Transmission Rate Test, Introns Universal Testing Instrument (Zwick Z.05 texture analyser), and colour index books,

This research was conducted in Completely Randomized Design with multiple factors. The first factor was the concentration of essential oil consisting of five levels: $0 \%$ essential oil, $2 \%$ lemon essential oil; lemon essential oil 3\%; essential oil of betel leaf $0.1 \%$; Essential oil of betel leaf $0.2 \%$. The second factor was the concentration of CMC with two levels: $1 \% \mathrm{CMC}$ and $1.5 \% . \mathrm{CMC}$

\section{B. Preparation of the Film Forming Solutions}

CMC film forming was done by heating $600 \mathrm{~mL}$ of distilled water at a temperature of $90^{\circ} \mathrm{C}$. CMC powder was added according to treatment and stirred until forming a CMC solution. $1.5 \%$ glycerol was added in the solution and then stirred until being homogeneous. Essential oils were put into CMC solution according to the treatment and stirred slowly until a homogeneous solution was formed. CMC solution was poured on an acrylic glass plate and stored at a room temperature for one week until drying and forming the edible film. Edible film was then released from acrylic to be cut into pieces according to the parameter requirements. The 
concentrations of edible coating ingredients used in these formulations were set up based upon reference [9] and reference [10].

\section{Application of Edible Coating}

Apple fruit was brought to the laboratory to be sorted and washed with $50 \mathrm{ppm}$ chlorine solution and cut into $2 \mathrm{x} 1.5 \mathrm{x}$ $1 \mathrm{~cm}$. The fresh-cut was dipped according to the treatment before being drained. The fresh-cut was placed in styrofoam and covered with wrapping film. Fresh-cut that has been treated and packaged then stored in a refrigerator with temperature of $4^{0} \mathrm{C}$. The observations were made on the day $(0,3,6,9,12$, and 15) according to the observation parameters.

\section{Water Vapor Transmission Rate}

The test on water vapour permeability in this film aimed to determine the velocity of water vapour transmission. The test was done by cutting the edible film into a circle with a diameter of $8 \mathrm{~cm}$. Edible films were tested on WVTR devices conducted at the Engineering Laboratory, Faculty of Agricultural Technology, Gajah Mada University.

First, jars were filled with $40 \%$ concentration of salt solution using $\mathrm{NaCl}$ by dissolving 40 grams $\mathrm{NaCl}$ with water. The cup was then filled with blue silica gel. The tested film was sealed and waxed on the edge of the film in contact with the cup. The cup was placed in a jar set with $77 \% \mathrm{RH}$ with $40 \% \mathrm{NaCl}$ solution at $25^{\circ} \mathrm{C}$. The size of the cup was $7.45 \mathrm{~cm}$ in diameter, $8.45 \mathrm{~cm}$ in outer diameter, and $2.65 \mathrm{~cm}$ in depth. Weighing was carried out every hour within 7 hours and then the slope was calculated between the weight change and the storage time. The rate of water vapour transmission was determined by equation:

$$
\mathrm{WVTR}=\frac{\text { Slope }}{\mathrm{A}}(\mathrm{g}) /(\mathrm{m} 2) \text { (hour) }
$$

Note: $\mathrm{A}=$ area of film

\section{E. Tensile Strength}

The tensile strength was measured to determine the amount of force achieved to achieve a maximum pull in each unit of film area to stretch or elongate [11]. Instron Universal Testing Machine was used to measured tensile strength and percentage of elongation. This test was conducted at the Engineering Laboratory, Faculty of Agricultural Technology, Universitas Gadjah Mada. The method was started by cutting the edible film with into $12 \mathrm{~cm} \times 5 \mathrm{~mm}$ each piece, and then horizontally placed on the UTM device and analyzing the results directly visible on the computer. Outgoing results were in the form of thickness value, tensile strength and elongation. The sample was cut in certain shape (according to the specifications of the tool) and certain size and installed on the tool. Tensile strength was determined by the equation below.

$$
\text { Tensile strength }=\frac{\mathrm{F} \text { max }}{\mathrm{A}}
$$

Note: $\mathrm{F} \max =$ Maximum force to break the film

\section{F. Elongation}

Length increase was measured using the zwick instrument. The output detected was the initial length and maximum length of the film. Elongation was determined by the following equation:

$$
\text { Elongation }=\frac{\mathrm{L} 0-\mathrm{Lc}}{\mathrm{Lc}} \times 100 \%
$$

Note: $\mathrm{L} 0=$ initial length, $\mathrm{LC}=$ final maximum length

\section{G. Biodegradability}

Soil Burial Test was used to measured biodegradability of edible film. It was started by cutting the film with a size $(5 \times 5)$ $\mathrm{cm}$ by 3 pieces in each treatment. The cut film was then buried in the ground for one week, then observeed was done on the film area were left and calculated using area meter.

\section{H. Solubility in Water}

The percentage of solubility of edible film is the percentage of the film dissolved in water after soaking for 24 hours [12]. The sample was cut into to $3 \times 3 \mathrm{~cm}$ and placed in an aluminium cup which has previously been dried and weighed. Edible coating samples were put into an oven at $100^{\circ} \mathrm{C}$ for 30 minutes. Weigh dry sample weight as initial dry weight (w0), then sample soaked for 24 hours in $50 \mathrm{ml}$ aquades. After 24 hours, the unsolved sample was removed and dried in an oven for 2 hours at $100^{\circ} \mathrm{C}$ and weighed as the sample weight after immersion (w1). The percentage of solubility of samples in water (S) was calculated by the equation below:

$$
\text { Solubility in water }=\frac{w 0-w 1}{w 0} \times 100 \%
$$

Note: $\mathrm{W} 0=$ initial weight, $\mathrm{W} 1=$ final weight

\section{Colour and browning index}

Colour and browning testing was done qualitatively based on the level of preference for the quality of manalagi apples. Testing was done by selecting 10 panellists to measure the level of preference using scoring 1-5 as 1 for dislike and 5 for like.

$$
\text { Score }=\frac{(\text { Score } x \text { Number of panelist })}{\text { Total panelist }}
$$

\section{J. Antibacterial Activity}

Microbiological tests were carried out within $0,3,6,9,12$, and 15 days of storage by counting the total microbes using the plate count method [13]. Medium Nutrient Agar (NA) was made as much as $1,000 \mathrm{ml}$. The medium was homogenized and sterilized by autoclave on $1 \mathrm{~atm}$ for 20 minutes. $1 \mathrm{~g}$ fruit, which had been mashed was then put into a tube containing 9 $\mathrm{ml}$ of sterile aquadest before being homogenized with vortex. A 0,1-ml sample solution was diluted into $10 \mathrm{ml}$ medium, which had been poured in petridish. The petridish was incubated for 2 days at the room temperature. The number of microbes growing on petridish was calculated by colony counter and the result of the calculation was presented in log Colony Forming Unit (CFU).

\section{K. Data Analysis}

Observation data were analyzed using SAS software and Duncan Multiple Range Test was performed at 5\% error level for comparison. 


\section{RESULTS AND DISCUSSION}

A. Water Vapor Transmission Rate

Table 1 . Water vapor transmission rate $(\mathrm{g} \mathrm{h} 20 / \mathrm{m} 2 / \mathrm{h})$ of CMC based edible coating enriched with essential oils

\begin{tabular}{|c|c|c|c|c|c|c|}
\hline \multirow{3}{*}{ Treatment } & \multicolumn{5}{|c|}{ Essential Oils } & \multirow{3}{*}{ Means } \\
\hline & \multicolumn{4}{|c|}{ Lemon } & \multirow{2}{*}{$\begin{array}{l}\begin{array}{l}\text { Betel } \\
\text { Leaf }\end{array} \\
0.2 \% \\
(M 4)\end{array}$} & \\
\hline & $\begin{array}{c}0 \% \\
(M 0)\end{array}$ & $\begin{array}{c}2 \% \\
(M 1)\end{array}$ & $\begin{array}{c}3 \% \\
\text { (M2) }\end{array}$ & $\begin{array}{l}0.1 \% \\
\text { (M3) }\end{array}$ & & \\
\hline $\mathrm{CMC} 1 \%(\mathrm{C} 1)$ & 31.40 & 28.86 & 28.48 & 24.10 & 23.40 & $27.25 \mathrm{a}$ \\
\hline CMC 1.5\% (C2) & 22.50 & 26.04 & 24.73 & 24.13 & 22.41 & $23.96 \mathrm{~b}$ \\
\hline Means & $26.95 \mathrm{a}$ & $27.45 \mathrm{a}$ & $26.61 \mathrm{a}$ & $24.12 b$ & $22.90 \mathrm{~b}$ & $(-)$ \\
\hline
\end{tabular}

Table 1 stated that the means between CMC treatments were different significantly. The average CMC treatment concentration of $1 \%(\mathrm{C} 1)$ was higher than the mean $\mathrm{CMC}$ concentration of $1.5 \%(\mathrm{C} 2)$. It is alleged that $\mathrm{CMC}$ with a concentration of $1.5 \%$ had high density with the result showing its ability to restrain the rate of water vapour; while CMC with a concentration of $1 \%$ had a lower density with that result showing that it was easily traversed by water vapour. CMC with a concentration of $1.5 \%$ had more dissolved than $\mathrm{CMC}$ with a concentration of $1 \%$.

According to reference [14], the high concentration of an edible film would increase the number of film-forming polymers and total solids with the result that thick edible films would be formed. The increase of of polymer would reduce the cavity in the gel formed, and the thicker and denser film matrix formed could reduce the water vapour transmission rate with the result that water vapour is difficult to transmit.

Table 1 shows that the mean between the treatments of essential oils was different significantly. The mean treatment of CMC essential oil 0\% (M0) was higher than the means treatment of $\mathrm{CMC}$ essential oils of betel leaf at various concentrations (M3 and M4).

Reference [15] stated that polymers with high hydrophilic groups would produce films susceptible to moisture, whereas polymers with high hydrophobic groups would produce films with good resistance to moisture. Essential oils are capable of improving the hydrophobic of CMC edible film. Hence, the resistance of edible films to water vapour increases with the increasing concentration of essential oils in edible films CMC. Reference [16] showed that the addition of essential oils of Boesenbergia rotunda had a significant effect on the water vapour transmission rate of edible film and an increase in the concentration of essential oils causes a decrease in the value of water vapour transmission due to containing a non-polar group with the result that it has good resistance to water vapour. Good resistance to water vapour described as resisting water molecules, the water vapour difficult to transmit [17].

\section{B. Tensile Strength}

Table 2. Tensile strength (Mpa) of CMC based edible coating enriched essential oil

\begin{tabular}{lllllll}
\hline \multirow{2}{*}{ Treatment } & \multicolumn{5}{c}{ Essential Oil } & \\
\cline { 2 - 6 } Means \\
\cline { 2 - 6 } & $0 \%(\mathrm{M} 0)$ & $2 \%(\mathrm{M} 1)$ & $3 \%(\mathrm{M} 2)$ & $0.1 \%(\mathrm{M} 3)$ & $0.2 \%(\mathrm{M} 4)$ & \\
\hline CMC 1\%(C1) & $0.31 \mathrm{de}$ & $0.22 \mathrm{e}$ & $0.25 \mathrm{e}$ & $0.53 \mathrm{c}$ & $0.38 \mathrm{cde}$ & 0.34 \\
\hline CMC 1.5\% (C2) & $0.56 \mathrm{c}$ & $0.47 \mathrm{~cd}$ & $0.30 \mathrm{de}$ & $0.86 \mathrm{~b}$ & $1.22 \mathrm{a}$ & 0.68 \\
\hline Means & 0.44 & 0.34 & 0.28 & 0.69 & 0.80 & $(+)$ \\
\hline
\end{tabular}

Table 2 shows each of CMC treatment at various concentrations of essential oils was different significantly. $\mathrm{CMC}$ treatment of $1 \%$ concentration with the addition of $0.2 \%$ betel leaf essential oil (C2M4) had the higher tensile strength compared to other treatments. There was a significant difference between the treatment of CMC $1 \%$ essential oil $0.2 \%(\mathrm{C} 1 \mathrm{M} 4)$ and $\mathrm{CMC} 1.5 \%$ essential oil of betel leaf $0.2 \%$ (C2M4). The higher concentrations of CMC for edible films would increase the binding $\mathrm{CMC}$ molecules with result showing that the $\mathrm{CMC}$ would not break easily by pulling force [18]. Research conducted by reference [19] using CMC with concentrations among $0 \%, 0.25 \%$ and $0.5 \%$ combined with $2.5 \%, 3.5 \%$ and $4.5 \%$ potato starch resulting that the increase value of tensile strength caused by the higher concentration of the CMC in edible film formula.

Table 2 also shows some significant differences between the treatment of CMC without essential oils and the one with the addition of various essential oils. CMC $1 \%$ treatment with the addition of $0.1 \%$ betel leaf $0.1 \%(\mathrm{C} 1 \mathrm{M} 3)$ essential oil had the higher tensile strength compared to $1 \% \mathrm{CMC}$ treatment without essential oil (C1M0). Research conducted by reference [20] showed that CMC with a concentration of $1 \%$ resulting the tensile strength value of $0.34 \mathrm{Mpa}$. Reference [21] stated that $\mathrm{CMC}$ of $1 \%$ with the addition of 0.4 grams of glycerol resulting the tensile strength value of $0.24 \mathrm{MPa}$. In this study, CMC $1 \%$ with the addition of $0.1 \%$ betel leaf essential oil and $0.2 \%$ was $0.53 \mathrm{MPa}$ and $0.38 \mathrm{MPa}$. This stated that CMC combined with other ingredients had the higher tensile strength compared to the use of CMC as a single ingredient in edible film formula.

\section{Elongation}

Table 3. Elongation (\%) of CMC based edible coating enriched essential oils

\begin{tabular}{lcccccc}
\hline \multirow{2}{*}{ Treatment } & \multicolumn{5}{c}{ Essential Oils } \\
\cline { 2 - 6 } & \multicolumn{5}{c}{ Lemon } & \multicolumn{3}{c}{ Betel Leaf } & Means \\
\cline { 2 - 6 } & $\mathbf{0 \% ( M 0 )}$ & $\mathbf{2 \% ( M 1 )}$ & $\mathbf{3 \%}(\mathbf{M 2})$ & $\mathbf{0 . 1 \% ( M 3 ) 0 . 2 \% ( M 4 )}$ \\
\hline CMC 1\% (C1) & $156.7 \mathrm{e}$ & $185 \mathrm{de}$ & $250.6 \mathrm{~b}$ & $206.7 \mathrm{~cd}$ & $176.7 \mathrm{de}$ & 195.13 \\
\hline CMC 1.5\% (C2)208.8cd & $231.1 \mathrm{bc}$ & $184 \mathrm{de}$ & $177.2 \mathrm{de}$ & $311.3 \mathrm{a}$ & 222.47 \\
\hline Means & 182.7 & 208.05 & 217.29 & 191.96 & 244 & $(+)$ \\
\hline
\end{tabular}

Table 3 shows each CMC treatment at various concentrations of essential oils was different significantly. CMC with a concentration of $1.5 \%$ provided a higher percentage of elongation compared to $\mathrm{CMC} 1 \%$ at various concentrations of essential oils. The use of CMC in larger amount caused better water binding ability with the result that it provided a gel matrix capable of increasing the percent length of the edible film because $\mathrm{CMC}$ had the high gel strength. Reference [22] stated that the addition of CMC has caused the gel to be more elastic with the result that the more elastic gel increasing the percent value of elongation. 


\section{Biodegradability}

Table 4. Biodegradability (\%) of CMC based edible coating enriched essential oils

\begin{tabular}{|c|c|c|c|c|c|c|}
\hline \multirow{3}{*}{ Treatment } & \multicolumn{5}{|c|}{ Essential Oil } & \multirow{3}{*}{ - Means } \\
\hline & \multicolumn{4}{|c|}{ Lemon } & \multirow{2}{*}{$\begin{array}{l}\text { Betel Leaf } \\
0.2 \%(M 4)\end{array}$} & \\
\hline & $\begin{array}{c}0 \% \\
(M 0) \\
\end{array}$ & $2 \%(M 1)$ & $3 \%(M 2)$ & $\begin{array}{l}0.1 \% \\
(M 3) \\
\end{array}$ & & \\
\hline $\begin{array}{l}\text { CMC 1\% } \\
(\mathrm{C} 1)\end{array}$ & 100 & 100 & 100 & 100 & 100 & $100 \mathrm{a}$ \\
\hline $\begin{array}{l}\text { CMC 1.5\% } \\
\text { (C2) }\end{array}$ & 100 & 98.67 & 98.67 & 97.33 & 96 & $98.13 b$ \\
\hline Means & $100 \mathrm{a}$ & $99.33 \mathrm{ab}$ & $99.33 \mathrm{ab}$ & $98.67 \mathrm{ab}$ & $98 \mathrm{~b}$ & $(-)$ \\
\hline
\end{tabular}

Table 4 shows the mean between CMC treatments was different significantly. The CMC concentration of $1 \%$ had a higher biodegradability compared to $\mathrm{CMC}$ concentration of $1.5 \%$. Basically, $\mathrm{CMC}$ is a linear polymer ether and in the form of compounds that have high biodegradable properties for coming from natural material that is wood cellulose. A research conducted by reference [23] showed that CMC 5\% had the higher biodegradability of $100 \%$ compared to CMC with a concentration of $10 \%$ with the biodegradability by $75.57 \%$. This has proven that the lower concentration of CMC would increase biodegradability.

Table 4 also shows that the mean treatment of CMC without essential oils was significantly different from the mean CMC treatment combined with $0.2 \%$ betel leaf essential oil. The low value of biodegradability was due to the high concentration of CMC and addition of essential oil of betel leaf serving as an antimicrobial with the result showing the process of decomposition of edible films on the soil slower than edible film CMC as single ingredient. Essential oil from betel leaf contained $30 \%$ phenol. Phenol can cause damage to bacterial cells, denaturize proteins, activate enzymes and cause cell leakage [24]. The mechanism of phenol as an anti-bacterial agent acted as a toxin in the protoplasm, damaging and penetrating walls and precipitating bacterial cell proteins. Large molecular phenolic compounds can activate essential enzymes in bacterial cells even in very low concentrations. It caused edible film CMC with addition essential oil resulting lower value of biodegradability, even in lowest concentration $(0.1 \%)$.

\section{E. Solubility in water}

Table 5. Solubility in water (\%) of CMC based edible coating enriched essential oils

\begin{tabular}{|c|c|c|c|c|c|c|}
\hline \multirow{3}{*}{ Treatment } & \multicolumn{5}{|c|}{ Essential Oil } & \multirow{3}{*}{ Means } \\
\hline & \multicolumn{3}{|c|}{ Lemon } & \multicolumn{2}{|c|}{ Betel Leaf } & \\
\hline & $0 \%$ & $2 \%$ & $3 \%$ & $0.1 \%$ & $0.2 \%$ & \\
\hline CMC $1 \%$ & 100 & 100 & 100 & 100 & 100 & $100 \mathrm{a}$ \\
\hline CMC $1.5 \%$ & 100 & 100 & 100 & 100 & 100 & $100 \mathrm{a}$ \\
\hline Means & $100 \mathrm{a}$ & $100 \mathrm{a}$ & $100 \mathrm{a}$ & $100 \mathrm{a}$ & $100 \mathrm{a}$ & $(-)$ \\
\hline
\end{tabular}

Table 5 shows each treatment or means treatment of CMC and essential oils was not different significantly. All treatments had the good percentage of solubility in water, this is presumably because the bonds between CMC molecules were more tenuous with the result proving that water molecules were easily associated with CMC molecules. This is also because the CMC used to make edible films was a CMC with DS value of 0.7 or about 7 Carboxymethyl groups per 10 units of anhydroglucose, with the result that capable of being easily dissolved in water even though the difference in CMC concentrations of $1 \%$ and $1.5 \%$ [25].

\section{F. Colour and Browning Index}

Table 6. Colour and browning index of CMC based edible coating enriched essential oils

\begin{tabular}{lccccc}
\hline \multirow{2}{*}{ Treatment } & $\mathbf{3}$ & $\mathbf{6}$ & $\mathbf{9}$ & $\mathbf{1 2}$ & $\mathbf{1 5}$ \\
\cline { 2 - 6 } & Score & Score & Score & Score & Score \\
\hline C1M0 & 3.8 & 3.6 & 3.5 & 3.5 & 3 \\
\hline C2M0 & 3.8 & 3.6 & 3.5 & 3.5 & 2.8 \\
\hline C1M1 & 4 & 3.8 & 3.6 & 3.5 & 3 \\
\hline C1M2 & 4 & 3.8 & 3.6 & 3.3 & 2.8 \\
\hline C1M3 & 3 & 3 & 3 & 3 & 2.3 \\
\hline C1M4 & 3 & 3 & 3 & 3 & 2.3 \\
\hline C2M1 & 4 & 3.8 & 3.6 & 3.3 & 3 \\
\hline C2M2 & 4 & 3.8 & 3.6 & 3.1 & 2.8 \\
\hline C2M3 & 3 & 3 & 3 & 3 & 2 \\
\hline C2M4 & 3 & 3 & 3 & 3 & 2.1 \\
\hline
\end{tabular}

Table 6 shows that on the $3^{\text {rd }}$ day until the $15^{\text {th }}$ day, the score given by the panellists in each treatment showed a decrease in score. The lowest score since the 3rd day until the 15 th day was found in CMC treatment combined with betel leaf essential oil. The level of the panelist's preference for fresh-cut coated with CMC with the addition of essential oil of betel leaf was reduced because the colour had changed to brownish red. This colour may be caused by phenol compounds in essential oils of betel leaf. According to reference [26], betel leaves contain the essential oils, representing one third of phenols. This phenol compound caused enzymatic browning [27].

\section{G. Microbiology}

Table 7. Microbiology of CMC based edible coating enriched essential oils

\begin{tabular}{lcccccc}
\hline \multirow{2}{*}{ Treatment } & \multicolumn{6}{c}{ Day $\left(\mathbf{1 0} \mathbf{1 0}^{\wedge} \mathbf{C F U} / \mathbf{m l}\right)$} \\
\cline { 2 - 7 } & $\mathbf{0}$ & $\mathbf{3}$ & $\mathbf{6}$ & $\mathbf{9}$ & $\mathbf{1 2}$ & $\mathbf{1 5}$ \\
\hline C1M0 & 0 & 48.5 & 78 & 95 & 1900 & Spreader \\
\hline C2M0 & 0 & 81.5 & 36.5 & Spreader & 1100 & Spreader \\
\hline C1M1 & 0 & 98.5 & 37 & 51 & 159 & 326 \\
\hline C1M2 & 0 & 83 & 41 & 0 & 95 & 121.5 \\
\hline C1M3 & 0 & 81 & 0 & Spreader & 224 & Spreader \\
\hline C1M4 & 0 & 191 & 0 & 42 & 139.5 & 330 \\
\hline C2M1 & 0 & 87 & 0 & 56 & 87 & 109 \\
\hline C2M2 & 0 & 105 & 0 & 0 & 51 & 62 \\
\hline C2M3 & 0 & 95 & 49 & 77 & Spreader & 259.5 \\
\hline C2M4 & 0 & 98.5 & 57 & 71.5 & Spreader & 153 \\
\hline & & & & & &
\end{tabular}

The same level of bacterial growth occurred in the treatment CMC coating $1 \%$ and $1.5 \%$ on essential oils betel leaf. In the addition of lemon essential oil at various concentrations of CMC, no spreader was found. This indicated that the population and growth of bacteria in the treatment could be inhibited. Besides being able to inhibit the bacterial population, the treatment was also able to inhibit bacterial population growth until the $15^{\text {th }}$ day of storage. This is consistent with the statement of reference [28] that the hydrophobic properties of essential oils was able to pass through microbial cell membranes and enter mitochondria, 
disrupt internal structure and render the membrane more permeable.

The nti-bacterial compounds can occur through several mechanisms namely by inhibiting the bacterial growth through a reaction with cell membranes and by inactivating essential enzymes or genetic material. Furthermore, tannin compounds can form complexes with proteins through hydrophobic interactions and then from these bonds it will cause denaturation and disrupted cell metabolism; thereby killing bacterial cells [29].

Lemon essential oil has been successfully used as an antimicrobial in gram positive and gram negative bacteria [30]. Chitosan edible coating combined with lemon essential oil with a concentration of $3 \%$ became alternative treatment to extend the shelf-life of strawberry [31].

\section{CONCLUSION}

Increasingly, the $\mathrm{CMC}$ concentration showed an ability to improve the physical properties of edible films. CMC with $1.5 \%$ showed the greatest value on the physical properties of edible films by minimizing the rate of water vapour transmission and increasing tensile strength and percent of elongation. The addition of $0.2 \%$ betel leaf essential oil was able to improve the physical properties of edible films by minimizing the rate of water vapour transmission and increasing tensile strength and percent elongation. The addition of essential oils was not able to inhibit browning in fresh-cut apples. On the other hand, the addition of 3\% lemon essential oil combined with $\mathrm{CMC}$ was able to inhibit microbial growth in fresh-cut apples.

\section{ACKNOWLEDGMENT}

The author thanks to Ministry of Higher Education especially DRPM DIKTI for funding this work. This work has also been supported by the Dean of Faculty of Agriculture, Universitas Muhammadiyah Yogyakarta.

\section{REFERENCES}

[1]. Rojas-Graü, M. A., Tapia, M. S., Rodríguez, F. J., Carmona, A. J., and Martin-Belloso, O., "Alginate and Gellan Based Edible Coatings as Support of Antibrowning Agents Applied on Freshcut Fuji Apple.," Food Hydrocolloids, pp. 118-127, 2007.

[2]. Rojas-Grau, M. A., Tapia, M.S., and Martin-Belloso, O, "Using Polysaccharide-based Edible coatings to Maintain Quality of Fresh-cut Fuji Apples," Lebensmitted Wissenschaft und Technologie, pp. 139-147, 2008.

[3]. Gol, N.B., P.R. Patel, T.V. Rao, "Improvement of Quality and Shelf-life of Strawberries with Edible Coatings Enriched with Chitosan," Postharvest Biology Technology, pp. 185-195, 2013.

[4]. Chao, S., G. Young, C. Oberg, and K. Nakaoka, "Inhibition of Methicillin Resistant Staphylococcus aureus (MRSA) by Essential Oils," Flavour and Fragrance Journal, pp. 444-449, 2008.

[5]. Sokovic, M., Glamoclija, J., Marin, P.D., Brkic, D. and Griensven, L.J.L.D.,, "Antibacterial Effect of the Essential Oils of Commonly Consumed Medicinal Herbs Using an In Vitro Model," Molecules, pp. 7532-7546, 2010

[6]. Borgou, S., Rahali, F.Z., Ourghemmi, I. \& Tounsi, M.S.,, "Changes of Peel Essential Oil Composition of Four Tunisian Citrus during Fruit Maturation," The Scientific World Journal, pp. 1100-1110, 2012.

[7]. R. Z. Nalina T, "The Crude Aqueous Extract of Piper Betel L and Its Antibacterial Affect Towards Streptococcus mutans," Am J Biochem \& Biotech, pp. 226-236, 2007.
[8]. Massilia, R.M.R., J. Mosqueda-Melgar, and O. Martin Belloso., "Edible Alginate-based Coating as Carrier of Antimicrobials to Improve Shelf-life and Safety of Fresh-cut Melon," Intl. J. Food Microbiol, p. 313-327, 2008.

[9]. H. Amon, R. Granit, R. Porat and E. Poverenov, "Development of Polysaccharides-Based Edible Coatings for Citrus Fruits: A Layer-by-Layer Approach," Food Chemistry, vol. 166, pp. 456472, 2015

[10]. B. Prakash, R. Shukla, P. Singh, A. Kumar, P. K. Mishra and N. K. Dubey, "Efficacy of Chemically Characterized Piper Betle L. Essential Oil Against Fungal and Aflatoxin Contamination of Some Edible Commodities and its Antioxidant Activity," Ijt. J. Food Microbiol, vol. 142, pp. 114-119, 2010.

[11]. J. M. Krochta and J. C. M., "Edible Film and Biodegradable Polymer Film Challenger and Opportunities," Food Tech, vol. 51, no. 2, pp. 61-74, 1997.

[12]. Turhan, K. N., and F. Sahbaz., "Water Vapor Permeability, Tensile Properties, and Solubility of Methycellulose-based Edible Films," Journal Food Science, pp. 459-466, 2004

[13]. Jutono, J., Soedarsono, S., Hartadi, S., Kabirun, S., Suhadi, D. dan Soesanto., Pedoman Praktikum Mikrobiologi Umum., Yogyakarta: Departemen Mikrobiologi Fakultas Pertanian UGM, 1980.

[14]. H. K. Dyah and D. R. P. Widya, Karakteristik Fisik dan Kimia Edible Film Pati Jagung yang Diikorporasi dengan Perasan Temu Hitam, Malang: Universitas Brawijaya, 2013.

[15]. Kester JJ, Fennema O., "Edible Film and Coating : A review," Food Technology, pp. 47-59, 1986

[16]. Miksusanti, Jennie BSL, Syarief R, Ponjto B, Trimulyadi G., "Kerusakan Dinding Sel Escherichia coli K1.1 oleh Minyak Atsiri Temu Kunci (Kaempferia pandurata Roxb)," Berita Biologi LIPI, pp. 1-8, 2008.

[17]. Fennema O, Donhowe IG, and Kester JJ., "Lipid Type and Location of the Relatife Humidity Gradient Influence on the Barrier Properties of Lipids to Water Vapor," J of Food Engineering, pp. 225-239, 1994.

[18]. Xu, Y.X., K.M. Kim, M.A. Hanna and D. Nug, "Chitosan-starch Composite Film: Preparation and Characterization," Industrial Crops Products, pp. 185-192, 2005

[19]. P. N. Rachel, A. M. A. and Sudamo, Karakterisasi Edible Film dari Pati Propagul Mangrove Lindur (Bruguiera gymnorrhiza) dengan Penambahan Carboxymethyl cellulose (Cmc) sebagai Pemlastis, Surabaya: Universitas, 2011

[20]. Ghandarbazeh, B., H. Almasi, "Physical Properties of Edible Emusified Films Based on Carboxymethyl Cellulose and Oleic Acid," International Journal of Biological Macromoleculs, 2011.

[21]. Sayanjali, S., B. Ghandarbazeh, and S. Ghiassifar, "Evaluation of Antimicrobial and Physical Properties of Edible Film Based on Carboxymethyl Cellulose Containing Potassium Sorbate on Some Mycotoxigenic Aspergillus Species in Fresh Pistachios," LWT Food Science and Technology., 2011

[22]. Laxmikant., P. Kumar Borah., S. C. Deka., "Antimicrobial and Enzymatic Antibrowning Film used as Coating for Bamboo Shoot Quality Improvement," Carbohydrate Polymers, 2014.

[23]. Purwatiningsih S, Sjachriza A, Rachmanita, "Sintesis dan Optimalisasi Gel Chitosan-karboksimetil selulosa," J. Alchemy, pp. 57-62, 2007.

[24]. R.H. Yeti, Khasanah, Wibiana, Haryanto, "Pengaruh Penambahan CMC (Carboxymethyl Cellulose) Terhadap Tingkat Degradabilitas dan Struktur Permukaan Plastik Ramah Lingkungan.," in Simposium Nasional Teknologi Terapan, 2016.

[25]. K. Heyne, Tumbuhan Berguna Indonesia II. Diterjemahkan oleh Badan Litbang Kehutanan, Jakarta: Yayasan Sarana Wanajaya, 1987. 
[26]. K. Netty, "Pengaruh Bahan Aditif Cmc (Carboxyl Methyl Cellulose) Terhadap Beberapa Parameter Pada Larutan Sukrosa," ITENAS, Bandung, 2010.

[27]. F. G. Winarno, Kimia Pangan dan Gizi, PT Gramedia: Jakarta, 1997.

[28]. Rojas-Grau., Marla A., Robert Soliva-Fortuny., and Olga MartinBelloso., "Edible Coatings to Incorporate Active Ingredients to Fresh-cut Fruits : A Review.," Trends in Food Science \& Technology., pp. 438-447, 2009.

[29]. M. K. Ummah, Ekstraksi dan Pengujian Aktivitas Antibakteri Senyawa Tanin pada Daun Belimbing Wuluh (Averrhoa bilimbi L.), Malang: UIN Maulana Malik Ibrahim, 2010.

[30]. Espina, L., Somolinos, M., Loran, S., Conchello, P., García, D., and Pagan, R, "Chemical Composition of Commercial Citrus Fruit Essential Oils and Valuation of Their Antimicrobial Activity Acting Alone or in Combined Processes," Food Control 22, pp. 896-902, 2011.

[31].Perdonesa, L. Sánchez-Gonzáleza,b, A. Chiralta, M. Vargasa, "Effect of Chitosan-lemon Essential Oil Coatings on Storagekeeping Quality of Strawberry," Postharvest Biology and Technology., pp. 32-41, 2012. 